\title{
Pembentukan Karakter Disiplin bagi Siswa
}

\author{
Ahmad Taufik, ${ }^{1 *}$ Muhamad Akip ${ }^{2}$ \\ ${ }^{1,2}$ STAI Bumi Silampari Lubuklinggau, Indonesia \\ 1'ahmadtaufik201902@gmail.com, ${ }^{2}$ muhammdaakip@gmail.com
}

\begin{tabular}{lll}
\hline Received: $2021-04-07$ & Revised: 2021-06-15 & Approved: 2021-06-17 \\
*) Corresponding Author & & \\
Copyright (C2021 Authors & &
\end{tabular}

\begin{abstract}
This paper presents the role of Moslem education in shaping the character of student discipline. Many public school students still underestimate morality, manners, and disciplined behavior. Therefore, education is the center of Islam and the best solution to shape student discipline. Islamic education may be a method of deepening and appreciating knowledge. In this process, students learn Islamic values through the expansion and development of their natural abilities. They notice their potential for equality and excellence in life. The analysis methodology employed in this research is descriptive analysis; a collection of data and sources to analyze, explain critically, and understand more systematically the role of Islamic education in shaping student discipline. The results of the research show that the benefits of Islamic education can shape student discipline, including providing religious material, guidance, advice, recommendations, and role models for educators.
\end{abstract}

Keywords: Discipline, School, Students.

\begin{abstract}
Abstrak
Tulisan ini menyajikan tentang peran pendidikan Islam dalam membentuk sifat disiplin siswa. Banyak siswa sekolah umum masih meremehkan moralitas, sopan santun, dan perilaku disiplin. Oleh karena itu, pendidikan merupakan pusat Islam dan solusi terbaik untuk membentuk kedisiplinan peserta didik. Pendidikan Islam adalah proses pendalaman dan penghayatan ilmu. Dalam proses ini siswa mempelajari nilai-nilai keislaman melalui penumbuhan dan pengembangan kemampuan fitrahnya. Mereka menyadari potensi mereka untuk kesetaraan dan keunggulan dalam hidup. Metode penelitian yang digunakan dalam penelitian ini adalah deskriptif analisis; kumpulan data dan sumber untuk dianalisis, jelaskan secara kritis, dan pahami secara lebih sistematis peran pendidikan Islam dalam membentuk disiplin siswa. Hasil penelitian menunjukkan bahwa adanya peran pendidikan Islam dapat membentuk disiplin siswa, termasuk memberikan materi agama, bimbingan, nasihat, rekomendasi, dan model peran pendidik.
\end{abstract}

Kata Kunci: Disiplin, Sekolah, Siswa.

\section{Pendahuluan}

Dampak negatif globalisasi menyebabkan generasi muda kehilangan nilai-nilai moralnya. Akhlak mulia, memiliki sifat jujur, kesopanan, sikap tenggang rasa kepada manusia lain dan akhlak mulia lainnya seakan memudar pada anak kekinian dan sikap demikian adalah hal asing atau susah ditemukan masa sekarang. Nilai moral yang umum 
contohnya adalah sikap disiplin yang tidak mudah ditemukan pada siswa di sekolah, sehingga harus dilakukan upaya untuk mengembalikan nilai karakter disiplin kepada siswa melalui pembentukan karakter. Hal ini sejalan dengan latar belakang lahirnya reformulasi pendidikan karakter yang mempunyai lima nilai utama, yaitu religius, nasionalis, mandiri, gotong royong, dan integritas. Dalam hal ini disiplin merupakan salah satu subnilai nasionalis. ${ }^{1}$

Karakter adalah penilaian adaptasi timbal balik individual manusia bersama pencipta (tuhan), antar insan kamil, dan lingkungan kepada negara yang terbentuk secara spiritual, logis, dan berbasis perilaku berdasarkan nilai-nilai hukum, agama, dan hukum positif. Kepribadian ditentukan oleh tingkah laku, sikap atau tingkah laku yang diamati dalam kehidupan sehari-hari. Kepribadian bukan hanya sifat atau pembawaan, tetapi juga kepribadian seseorang itu sendiri yang bisa diintegrasikan melalui kebiasaan-kebiasaan pendukung maupun analisis sikap aktif. Kesadaran akan realitas lingkungan pendidikan, harus ada stimulus agar individu dapat memaknainya dengan pencapaian tujuan. ${ }^{2}$

Pembentukan kepribadian yang berkarakter dapat dicapai melalui pengaruh lingkungan, terutama pendidikan. Tujuan dari pembinaan karakter adalah orang-orang yang bermoral tinggi. Dalam penanaman karakter siswa, setiap guru harus menyadari bahwa penanaman karakter memerlukan bimbingan dan pendidikan moral bagi siswa, siswa tidak hanya menerima pengetahuan teoritis, tetapi juga perlu belajar, menghayati dan mengamalkan. Pendidikan harus bisa melahirkan anak didik berakhlak mulia dan bertanggung jawab agar terbiasa menghadapi tantangan dalam kehidupan global saat ini. ${ }^{3}$

Masalah kedisiplinan di sekolah seperti siswa yang menyebabkan kegaduhan ketika pelaksanaan pembelajaran sehingga menyebabkan dirinya dan siswa lain tidak memahami isi materi yang diajarkan oleh guru, siswa tidak masuk kelas sesuai aturan, dan berbagai pelanggaran tata tertib sekolah lainnya merupakan problem umum yang sering terjadi. Berbagai usaha yang dilakukan untuk menyelesaikan masalah kedisiplinan dalam konteks pembelajaran merupakan bagian dari proses pendidikan karakter. Pendapat ini sejalan dengan pernyataan Hidayat, dkk bahwa disiplin tidak bisa dimaknai

\footnotetext{
1 Tim Penyusun, Konsep dan Pedoman Penguatan Pendidikan Karakter; Tingkat Sekolah dasar dan Sekolah Menengah Pertama (Jakarta: Kemdikbud, 2019), https://cerdasberkarakter.kemdikbud.go.id/?wpdmpro=buku-konsep-dan-pedoman-ppk.

2 Ahmad Taufik, "Dakwah Pasca Covid 19," Jurnal Khabar: Komunikasi Dan Penyiaran Islam 2, no. 2 (30 Desember 2020): 167-75, https://doi.org/10.37092/khabar.v2i2.249.

${ }^{3}$ Muhamad Akip dan Ahmad Taufik, "Konsep Pendidikan Akhlak Perspektif Ibnu Qoyyim Al Jauziyyah Dan Bisri Mustofa," El-Ghiroh: Jurnal Studi Keislaman 19, no. 1 (1 April 2021): 15-32, https://doi.org/10.37092/el-ghiroh.v19i1.278.
} 
sebagai tindakan tunggal karena merupakan suatu proses agar siswa mampu memahami perilakunya sendiri, berinisiatif dan bertanggung jawab atas pilihan tindakan mereka, dan menghormati dirinya serta orang lain. ${ }^{4}$

Berkenaan dengan itu, beberapa hasil penelitian mengenai upaya mengatasi problem kedisiplinan siswa mempunyai penekanan dan cara tersendiri. Hasil penelitian Sobri, dkk mengidentifikasi kultur sekolah yang terbangun di SMK Anak Bangsa sebagai basis pembentukan karakter disiplin siswa yang terdiri dari artifak sekolah, tata tertib, upacara/ritus, dan nilai-nilai atau keyakinan yang diimani oleh seluruh warga sekolah. ${ }^{5}$ Kajian sejenis juga terjadi di SMP Al-Ikhlas Kediri yang menjadikan kegiatan keagamaan sebagai basis penguatan karakter disiplin siswa yang menekankan pada tiga bentuk disiplin yaitu disiplin waktu, disiplin belajar, dan disiplin perilaku. Kegiatan keagamaan yang dimaksud adalah program istigasah rutin yang dilaksanakan setiap hari sebelum jam pelajaran pertama berlangsung. ${ }^{6}$ Selanjutnya pada konteks pendidikan pesantren Karim dan Masrukin menunjukkan bahwa wali asuh mempunyai peran penting untuk menjaga dan membangun kedisiplinan santri untuk mengikuti seluruh kegiatan dan program yang ada secara tertib. $^{7}$

Secara konseptual, optimalisasi peran pendidikan Islam idealnya mampu mengatasi berbagai masalah kedisiplinan siswa. Hal serius mengenai peran pendidikan Islam secara umum dalam lingkungan siswa-siswa tampak kurang terwujudkan secara maksimal dan efektif, sehingga banyak di antara siswa tidak lagi disiplin hampir pada berbagai aspeknya. Meski demikian kenyataan tentang keberadaan fungsi asimilasi nilainilai kedisiplinan siswa, perilaku siswa dalam kehidupan sehari-hari menunjukkan tingkat kedisiplinan tertentu. Perkiraannya sama seperti saat mereka tiba di sekolah tepat waktu sebelum masuk kelas. Para siswa membuat apel di pagi hari dan masuk ke kelas secara tertib. Hal ini juga sesuai dengan penelitian Salsabila, dkk yang menemukan bahwa karakter disiplin siswa dapat dibentuk dengan adanya peran pendidikan Islam di

\footnotetext{
${ }^{4}$ Nur Hidayat, Danarti, dan Sri Darwati, "Disiplin Positif; Membentuk Karakter Tanpa Hukuman,” 3 Agustus 2016, http://publikasiilmiah.ums.ac.id/handle/11617/7840.

${ }^{5}$ Muhammad Sobri dkk., "Pembentukan Karakter Disiplin Siswa melalui Kultur Sekolah," Harmoni Sosial: Jurnal Pendidikan IPS 6, no. 1 (6 Maret 2019): 61-71, https://doi.org/10.21831/hsjpi.v6i1.26912.

6 Muhammad Muhlisin dan Edi Nurhidin, "Konstruksi Kedisiplinan Melalui Habituasi Kegiatan Keagamaan," Indonesian Journal of Islamic Education Studies (IJIES) 3, no. 2 (2020): 236-51, https://doi.org/10.33367/ijies.v3i2.1395.

${ }^{7}$ Iqbal Karim dan Ahmad Masrukin, "Peran Program Wali Asuh Dalam Membentuk Kedisiplinan Santri Pondok Pesantren Al Mahrusiyah Putra Lirboyo," Indonesian Journal of Humanities and Social Sciences

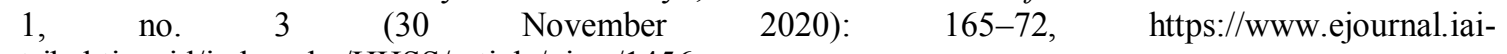
tribakti.ac.id/index.php/IJHSS/article/view/1456.
} 
antaranya melalui transfer pengetahun, pembiasaan, pemberian nasihat/teguran, dan keteladanan pendidik. $^{8}$ Atas dasar penjelasan di atas, lembaga pendidikan harus memaksimalkan peran pendidikan Islam dalam menciptakan dan membentuk karakteristik mata pelajaran agar mempunyai makna dan terwujudkan dalam kehidupan sehari-hari siswa. Sedangkan dalam proses pembelajaran formal di sekolah hal itu harus dilakukan melalui usaha mengintegrasikannya pada berbagai mata pelajaran dan kultur sekolah.

\section{Metode Penelitian}

Kajian ini menggunakan pendekatan kualitatif dengan jenis penelitian kepustakaan. Sumber data yang menjadi referensi kajian ini adalah buku, artikel jurnal, dan referensi lain yang relevan. Data yang sudah terkumpul dianalisis dengan metode analisis konten.

\section{Hasil dan Pembahasan}

\section{Karakter Disiplin Siswa}

Penjelasan karakter di sini mengacu pada konsep pendidikan karakter. Pendidikan karakter merupakan dimensi terdalam atau inti pendidikan nasional yang menjadi poros pelaksanaan pendidikan dasar dan menengah. ${ }^{9}$ Pendidikan karakter merupakan sistem penamaan nilai-nilai karakter pada seluruh warga sekolah pada tahapan pelaksanaan nilai karena sejatinya adalah upaya membiasakan warga sekolah agar bersikap dan berperilaku sesuai nilai-nilai tertentu melalui proses mengetahui, merasakan, mencintai, dan melakukannya. ${ }^{10}$ Istilah karakter sering dipahami secara analog dengan konsep akhlak dan moral. Moral berasal dari kata mos/mores yang dalam bahasa Yunani berarti adat kebiasaan atau cara hidup seseorang dengan melakukan perbuatan. Moral untuk penilaian perbuatan yang dilakukan, sedangkan etika adalah untuk pengkajian sistem nilai yang berlaku. Akhlak adalah sautu sikap yang tertanam dan mengakar dalam jiwa seseorang yang dapat melahirkan berbagai perbuatan tanpa harus mempertimbangkan terlebih dahulu. Adapun karakter adalah tabit, watak, sifat kejiwaan, budi pekerti yang

\footnotetext{
${ }^{8}$ Unik Hanifah Salsabila dkk., "Peran Pendidikan Islam Terhadap Pembentukan Karakter Disiplin Peserta Didik,” Jurnal Intelektual: Jurnal Pendidikan Dan Studi Keislaman 10, no. 3 (2020): 329-43, https://doi.org/10.33367/ji.v10i3.1391.

${ }^{9}$ Penyusun, Konsep dan Pedoman Penguatan Pendidikan Karakter, 5.

${ }^{10}$ Zaenal Arifin dan Moh Turmudi, "Character of Education in Pesantren Perspective," Tribakti: Jurnal Pemikiran Keislaman 30, no. 2 (8 Juli 2019): 335-48, https://doi.org/10.33367/tribakti.v30i2.823.
} 
membedakan seseorang dengan orang lain. Definisi ini mengindentikkan karakter dengan konsep akhlak dan kepribadian. ${ }^{11}$ Dengan kata lain, karakter atau akhlak dapat dimaknai sebagai perbuatan dalam kehendak jikalau tiap orang terbiasa akan bentuk ucapan beserta sikapnya dapat diaktualisasi dalam keseharian inilah yang dinamakan arti akhlak.

Disiplin adalah bentuk analisis dari hal keadaan diterapkan dengan proses-proses dan kegiatan perbuatan yang dilandasi norma ketertiban, kepatuhan dan saling pengertian. Orang yang sangat disiplin biasanya akan tepat waktu, mengikuti aturan dan konsisten. Aturan (organisasi-formal) yang ada dari kalangan lingkungan wajib dilaksanakan bagi tiap orang. Disiplin diartikan norma pengendalian tingkah laku manusia menurut doktrindoktrin yang dianutnya. Kontrol perilaku ini adalah ketaatan dan ketaatan terhadap perilaku kontrol, yang biasanya terstruktur dalam bentuk aturan atau peraturan lain. Dalam bentuk undang-undang yang berlaku untuk lembaga tertentu. Pernyataan tentang sikap psikologis pribadi atau sosial, yang menggambarkan perasaan ketaatan, ketaatan hati nurani untuk memenuhi tanggung jawab dan kepatuhan dalam mencapai tujuan mulia. Manfaat penting disiplin juga berkaitan dengan mengaktualisasi diri atas jelmaan pengikat norma. Berperilaku sebagai pribadi yang baik dengan mengontrol perilaku sesuai bersamaan kejadian-kejadian tiap kelompok community.

Selanjutnya adalah siswa yang berarti seseorang atau anak yang tengah belajar/berguru atau bersekolah khususnya pada jenjang pendidikan dasar hingga menengah karena pada tingkat pendidikan tinggi mereka disebut sebagai mahasiswa. Dalam pengertian pendidikan Islam diartikan sebagai orang-orang yang bisa memahami agama secara jasmani dan rohani guna memahami tujuan pasti dari pengetahuannya. Siswa dikenal aturan pendidikan Islam merupakan bagian dari sekelompok orang agar bisa mengaktualisasi dirinya melalui proses pemerolehan pembelajaran serta bisa ikut membentuk karakter sejati disertai iman, ilmu, takwa, dan berakhlak mulia agar melakukan kewajiban-kewajiban sebagai penghambaan kepada Allah SWT dan khalifah di muka bumi. ${ }^{12}$

\section{Pendidikan Islam}

Pendidikan merupakan pengetahuan terpenting serta hakikinya esensial bagi tiap orang. Pendidikan merupakan kewajiban yang diikuti dalam memajukan kedaulatan

\footnotetext{
${ }^{11}$ Aji Sofanudin, dkk., Literasi Keagamaan dan Karakter Peserta Didik, ed. oleh Aji Sofanudin dan Ahmad Muntakhib (Yogyakarta: Diva Press, 2020), 144.

${ }^{12}$ Ahmad Tafsir, Ilmu Pendidikan Perspektif Islam (Bandung: Remaja Rosdakarya, 2018), 11.
} 
negara maka dari sini manusia harus mengikuti jenjang pendidikan baik formal maupun informal, karena melalui pendidikan orang bisa bersikap lebih jujur dan tidak terjerumus dalam keburukan. Pendidikan adalah kondisi kehidupan yang paling penting. ${ }^{13}$ Tanpa pendidikan, hidup seperti rumah tanpa tiang. Yang terpenting adalah pendidikan Islam, karena hakikat sebuah analogi pendidikan Islam mengupayakan demi memperkuat dan mengembangkan karunia dari tiap orang, oleh karena itu, tujuan makhluk agar menjadi hamba Allah SWT dan khalifah-Nya di dunia saat ini adalah untuk mencapai tujuan sebanyak-banyaknya. Karunia yang ada dalam diri tiap individu tersebut merupakan potensi jasmani dan potensi rohaniah, meliputi kemauan, pikiran, dan lain-lain. Pendidikan Islam dapat berupa upaya memberikan layanan pendidikan kepada lembagalembaga sosial, atau bahkan urusan pribadi.

Pendidikan Islam adalah proses transformasi dan pembelajaran, dalam proses ini siswa mempelajari nilai-nilai Islam melalui penumbuhan dan pengembangan keterampilan untuk mencapai keseimbangan dan integritas dalam kehidupan. Dalam bidang pendidikan Islam, terdapat proses bagi siswa untuk memperkuat keimanan dan meningkatkan kepribadiannya sehingga dapat mempersiapkan generasi penerus untuk kehidupan yang lebih baik di bawah hukum Islam. Pendidikan yang diketahui dan dipelajari bisa dikombinasikan serta mampu menjalankan perintah Tuhan yang diikuti segala pribadi. Pendidikan Islam diakui dari manusia kepada sesuatu perwujudan dalam mengikuti segala aturan Tuhan Yang maha Esa dengan ikhlas dan menjalankan semua berkaitan perintahnya dan menjauhi segala yang dilarang-Nya. Akar dasar sebuah pendidikan keagamaan tidak saja wajib diamalkan bagi siapa saja, namun bisa dipahami dan mengikuti anjurannya pendidikan ini dapat dikenalkan dalam keluarga apalagi anak sedini mungkin.

Tujuan pendidikan Islam secara keseluruhan adalah membuat individu menjadi abdi Allah SWT. Tujuan pendidikan Islam sesuai dengan alur fungsi yang ditetapkan dari sisi perintah Allah bagi umat Islam, berupa untuk meningkatkan bentuk spiritual dan moralitas serta jiwa manusia tidak menyimpang sisi syariat Islam. Pentingnya pendidikan Islam dalam mengarungi kehidupan dunia adalah untuk mengakui bahwa Allah SWT, baik itu pribadi atau masyarakat umum. Pendidikan Islam mengajak atau membangun akhlak dan akhlak yang lebih baik, sehingga masa datang menghasilkan anak-anak yang

13 Arif Rohman, Pendidikan Komparatif Dasar-dasar Teori Perbandingan Pendidikan Antar Bangsa (Yogyakarta: Aswaja Pressindo, 2013), 16. 
lebih baik dan lebih mengerti agama Islam, pribadi mulia, memiliki tekad, mengetahui makna kewajiban dan cara menunaikannya, menghormati orang lain, membedakan yang baik dari yang buruk, dan fadilah. Fadilah menghindarkan hindari perilaku keji, dan selalu ingat Allah SWT dalam kondisi tertekan sekalipun.

Mengenai pemahaman dengan metode pendidikan berupa segala upaya-upaya yang dilalui oleh siswa saat terjadinya proses kegiatan belajar mengajar. Maksud mengenai "metode" adanya sikap timbal balik antara siswa dengan guru dalam mendasarkan fungsi mendidik, bisa disimpulkan bahwasannya metode adalah bentuk pengajaran yang baik dan sesuai dalam rambu-rambu dunia pendidikan. Ada beberapa metode yang terjadi penerapan pendidikan Islam, yakni untuk menumbuhkan rasa keimanan, biasa guru memakai metode hiwar, kisah qurani dan nabawi, metode amsal qurani dan nabawi, keteladanan, pembiasaan, ibrah, mauizah, dan yang terakhir targhib maupun tarhib.

\section{Pembentukan Karakter Disiplin pada Siswa}

Termasuk jenis-jenis pendidikan karakter, yang sering dikenal dengan pendidikan kewarganegaraan, pendidikan nilai, dan pendidikan moral. Istilah-istilah ini dapat merujuk sifat-sifat unggul agar dapat dikembangkan orang untuk membentuk kepribadian. Semua entitas yang berhubungan dengan hal-hal yang baik. Karakter memiliki kepribadian yang tetap, yaitu tetap sama secara kontinyu dalam dirinya. ${ }^{14}$ Misalnya, dari zaman dahulu hingga sekarang, disiplin dan kejujuran selalu menjadi kualitas yang baik. Oleh karena itu, pembentukan karakter harus dipertahankan dan dikembangkan untuk mencapai hasil yang positif. Pada dasarnya setiap orang di lembaga pendidikan telah belajar untuk hidup bersama dan meningkatkan kepekaan moralnya. Oleh karena itu, cakupan sekolah merupakan bidang pendidikan yang sangat penting. Ini membutuhkan orang-orang yang beretika, disiplin diri dan tekad yang berprinsip. Prinsip moral dianggap benar. Disiplin membantu siswa memahami dan memahami segala yang dapat dijadikan pondasi, apa yang tidak boleh dilakukan, maupun perbuatan termasuk dilarang. Bagi siswa yang sudah terintegrasi dengan mata pelajaran tersebut tidak terasa sebagai beban, sebaliknya tidak terbebani dengan disiplin.

Pembentukan karakter adalah proses penanaman sifat-sifat positif pada diri siswa berasal berbagai lingkungan keluarga, masyarakat, dan sekolah. Orang tua berperan

\footnotetext{
${ }^{14}$ Nur Uhbiyati, Dasar-dasar Ilmu Pendidikan Islam (Semarang: Pustaka Rizki Putra, 2013), 40.
} 
penting dalam membentuk karakter anaknya, dan orang tua mengajak sikap teladan indah dalam contoh pribadi sehari-hari. Kepribadian dalam masyarakat, jika siswa tinggal selama masih dianggap baik, itu akan berdampak baik pada kehidupannya, sebaliknya jika siswa tinggal selama masih lingkungan yang negatif atau tidak menguntungkan, itu akan berdampak negatif pada kehidupan mereka pula. Fungsi inilah seorang guru memegang peranan penting. Guru berperan dalam memajukan contoh dan siswa unggul. Oleh karena itu, pendidikan sangat penting untuk membentuk karakter peserta didik. ${ }^{15}$ Tiap siswa yang selalu tidak menyimpang mengenai aturan pembelajaran di sekolah tidak bisa melanggar atas peraturan-peraturan dan semua siswa harus mengikuti apapun peraturan-peraturan sekolahnya. Sikap disiplin yang terjadi di sekolah adalah upaya sekolah untuk mengajak dan teladan siswa-siswa sedemikian rupa supaya tetap baik serta memotivasi para siswa selalu berperilaku sesuai dengan tata tertib dan peraturan sekolah secara produktif. Hakikat pengertian tata tertib sekolah, antara lain peraturan bagaimana aturan berpakaian bagi siswa, tepat waktu saat datang, social community dan sistem pembelajaran berlangsung.

Berbicara tentang makna sekolah terlepas dari masalah perbuatan buruk siswa. Perbuatan buruk yang muncul akhir-akhir ini di kalangan pelajar remaja nampaknya sudah merajalela kepada anak bangsa, seperti kenyataan seks bebas, penyalahgunaan narkoba, gerombolan komunitas motor, dan apapun unsur-unsur pada kejahatan lain yang merugikan tidak hanya diri sendiri tetapi juga masyarakat. Mereka sering ditemukan mulai dari pelanggaran ringan hingga tingkat tinggi seperti membolos, berkelahi, menyontek, perampokan, dan bentuk perilaku menyimpang lainnya. Ranah sekolah yang taraf pengelolaan secara demokrasi, mandiri, dan dapat bertanggung jawab untuk mengembangkan siswa yang taat serta patuh disebabkan mereka sadar bahwa mereka mengikuti aturan yang berlaku, bukan karena mereka dipaksa, tetapi mengetahui bahwa itu baik dan bahwa sanksi itu bermanfaat.

Pada hakikatnya, disiplin adalah sesuatu perbuatan yang dibiasakan. Pelatihan perbuatan disiplin memiliki guna meningkatkan kendali diri, pribadi atau ketertiban, dan efisien. Hal ini bisa mempunyai kesimpulkan yakni disiplin berkaitan dengan apa saja berupa pengendalian diri agar melalui disiplin dapat menbedakan sikap yang dianggap hal begitu berupa kebenaran begitu juga hal tidak benar agar saat rencana jangka selanjutnya mengatasi masalah atau mengajak perbuatan siswa selalu mengerti tugasnya.

${ }^{15}$ Adian Husaini, Filsafat Ilmu Perspektif Barat dan Islam (Jakarta: Gema Insani, 2013), 18. 
Perbuatan siswa dibentuk dan diperoleh tanggung jawab berbagai faktor yang menjadikan siswa ke arah perbuatan yang menjadi identitasnya, antara lain faktor lingkungan, keluarga, dan sekolah. Kenyataannya identitas lembaga pendidikan atau sekolah adanya faktor-faktor yang mendominasi menjadi karakteristik dan dapat pengaruh keadaan beberapa siswa. Pada saat siswa mengikuti pembelajaran berlangsung, tentunya siswa menjalin hubungan emosional bersama para guru yang membimbing dan mengajarinya. Contoh, perbuatan/tindakan dan isi materi yang diperoleh, didengar, dan merupakan teladan yang patut diikuti dapat menembus hati mereka, dan hasil belajar yang diperoleh para siswa terkadang pengaruh perkataan seorang guru yang idealnya berbanding lurus dengan arahan orang tua.

Tindakan sikap disiplin ini adalah ihwal penting untuk mendukung keberhasilan aturan yang ditegakkan di sekolah di mana guru dan siswa berkumpul untuk menaati aturan yang ditegakkan guna menangkal perbuatan-perbuatan dari lingkungan sekitar. Oleh sebab itulah, menjadi orang tua harus mengerti perkembangan pribadi anaknya dan optimal dalam mengayomi anak guna menjadikan anaknya patuh dalam pekerjaan disiplin dan secara objektif supaya anak dapat kendali diri maupun emosional orang tua tersebut dalam membimbing anaknya. Keberadaan lingkungan sekolah, guru ialah bentuk orang tua yang patut diikuti bagi siswanya. Oleh karena itu, mendisiplinkan guru yang bisa disiplin dalam bersikap memiliki fungsi khusus terutama saat berlangsung kegiatan belajar mengajar. Sungguh mulia jika seorang pendidik tidak hanya menanamkan kedisiplinan pada siswanya, tetapi juga disiplin dan sanggup tanggung jawab atas ketentuan pekerjaan rumahnya.

Disiplin bukanlah suatu hukuman, perbudakan atau paksaan untuk ditaati. Sikap disiplin dimaknai sebagai perbuatan positif yang dapat mengubah dari penentuan nasib sendiri dalam masa akan datang, sehingga penetapan tata tertib dalam penerapan disiplin dalam proses pendidikan sangat diperlukan guna mengaktualisasikan tata tertib yang baik. Guru dapat menjalankan aturan-aturan sekolah terdapat faktor pendukung kegiatan yang selalu dikaitkan dengan aturan. Ini tidak terlepas juga dalam kejelasan disiplin saat siswa berada di kelas maupun aturan lainnya bagi warga sekolah.

Penerapan disiplin tidak saja berkelut dalam melihat hadir ataupun ketidakhadiran, datang kurang tepat waktu atau tidak absen sama sekali. Melainkan terkait dengan menciptakan lingkungan di mana aturan-aturan dibagikan dan pelaku pelanggar yang telah melanggarnya harus takluk bertanggung jawab. Di sekolah, mereka 
harus diberi hukuman pendidikan agar siswa memahami nilai disiplin tidak berharga untuk disiplin sendiri, tetapi untuk nilai yang akan diperoleh dalam artian secara luas, yaitu stabilitas dan perdamaian di antara komunitas warga sekolah. Disiplin sekolah adalah kepastian umum perilaku yang menjamin kondisi tingkah laku yang diberlakuan agar kemajuan prestasi sekolah mencolok dan bisa membanggakan. Disiplin dapat menjadi semacam tindakan pencegahan dan menyingkirkan hal-hal yang membahayakan nyawa siswa. Sekolah tanpa disiplin ibarat kincir air tanpa air.

Sikap disiplin sangat memudahkan guru dalam memberi teladan kepada para siswa guna mengurangi gejala buruk dikarenakan siswa yang mampu disiplin diajarkan terbiasa mengenal kebaikan indikasinya banyak siswa-siswa berbuat baik baik saat berada di sekolah maupun rumah. Proses siswa yang dapat disiplin memerlukan bimbingan, penguatan, serta teladan yang dipraktikkannya bersama para orang tua ataupun para guru dalam membiasakan insan kamil. ${ }^{16}$ Perlu digarisbawahi hakikat sikap disiplin dikenal seorang siswa sejak dini dalam pikiran mereka dan terjaga menjadi karakter siswa. Tentu dorongan dan komitmen jelas dari lingkungan sekolah juga menentukan disiplin para siswa disertai teladan dan bimbingan secara kontinyu.

Penerapan mata pelajaran ini dapat dikembangkan dengan adanya faktor pendukung seperti partisipasi orang tua. Sangat penting bagi orang tua untuk berpartisipasi dalam pendidikan disiplin anak sekolah karena mereka dapat memantau dan mengontrol perilaku siswa di rumah. Anak-anak belajar, bermain, beribadah, menonton TV dan sebagainya. Jika seorang siswa menunjukkan perilaku abnormal, orang tua harus memberi tahu sekolah sehingga mereka dapat menemukan solusi untuk mengatasi perilaku abnormal dan membiarkan siswa mengikuti aturan yang dianjurkan.

Seorang siswa dalam menjalankan disiplin diri tentu adanya lingkungan guna membentuk kebiasaan baik. Ketika saling interaksi dengan macam karakteristik temannya, seorang siswa akan menyadari nilai sesuatu nilai pendidikan. Belajar dalam lingkungan yang mengandung pembelajaran muncul aspek nilai tertentu dalam upaya membawa perilaku dan perubahan tingkah laku dipengaruhi oleh aspek bawaan yang dipahami siswa. Oleh karena itu indikator belajar adalah mengubah kebiasaan-kebiasaan anak dan mengubahnya bisa dilihat dari segala kondisi anak yakni hasil perubahan dari proses belajar. Pendidikan Islam juga berusaha untuk menemukan dan mendorong peserta

\footnotetext{
${ }^{16}$ Doni Kusuma, Pendidikan Karakter: Strategi Mendidik Anak di Zaman Global (Jakarta: Grasindo, 2017), 19.
} 
didik untuk membentuk dan membimbing karakter yang selalu berjasa, sehingga pendidikan Islam dapat mewujudkan fungsi pembentukan karakter. ${ }^{17}$ Selama siswa didukung dalam lingkungan yang mendukung, mereka pasti dapat menemukan nuansa pendidikan Islam di banyak tempat. ${ }^{18}$ Siswa harus menumbuhkan makna secara sadar akan kepatuhan terhadap peraturan dan disiplin yang ada. Pendidikan Islam sangat mementingkan masalah moral, termasuk gairah disiplin. Semua orang harus dapat disiplin dengan ketentuan aturan, kalau tidak mereka mendapat akibat fatal atas perbuatan halhal buruk mereka. Oleh karena itu, siswa perlu mendisiplinkan diri melalui masyarakat pendidikan Islam. ${ }^{19}$

Tujuan utama pendidikan sesuai syariat Islam adalah bisa menumbuhkan karakter para siswa yang dapat dikenali sebagai inspirasi perilaku dan mentalitasnya sehari-hari. Dukungan dan semangat dari pihak sekolah. Dukungan dari komunitas mahasiswa dan orang tua juga menjadi kunci penting. Sekolah harus mampu mengoordinasikan model pengajaran pendidikan agama Islam dan menularkannya kepada masyarakat yang saling mengawasi dan menginspirasi, sehingga dapat menumbuhkan karakter peserta didik dengan akhlak dan perilaku yang baik, menumbuhkan karakter disiplin siswa. Di sinilah pentingnya mempelajari pendidikan agama Islam, yang dapat mengantarkan anak didik dengan segudang ilmu, agama, dan pengetahuan. ${ }^{20}$ Sebab itulah, pengenalan pendidikan dengan sistem Islam di sekolah ialah salah satu kunci utama pembentukan karakter yang benar. Pendidikan Islam terutama mengajak akan landasan prioritas pengenalan sejak dini mengenai moralitas dengan menanamkan sadar dalam menjalankan pelajaran suatu agama kepada para siswa. Pendidik mengajarkan melalui dasar agama berdasarkan tauhid ilahiyah, pengetahuan ajaran Islam kehidupan sehari-hari, mengajarkan kualitas perilaku manusia sesuai akhlak, mengajarkan model kehidupan yang bersumber dari sejarah dan model kehidupan yang berazas dari Al-Qur'an dan Hadis Nabi.

Oleh karena itu, sekolah harus lebih memperhatikan pendidikan agama Islam. Dari segi karakteristik, pendidikan agama Islam harus digambarkan dalam tujuan atau sasaran, tidak hanya untuk menciptakan bahan ajar, tetapi juga untuk meningkatkan kualitas pendidikan karakter secara lebih luas. Pendidikan Agama Islam di lembaga pendidikan

\footnotetext{
${ }^{17}$ Ahmad Tantowi, Pendidikan Islam di Era Transformasi Global (Semarang: Pustaka Rizki Putra, 2008), 92.

${ }^{18}$ Hamdani Ihsan, Filsafat Pendidikan Islam (Bandung: Pustaka Setia, 2017), 22.

${ }^{19}$ Zubaedi, Desain Pendidikan Karakter; Konsepsi dan Aplikasinya dalam Lembaga Pendidikan (Jakarta: Kencana, 2011), 36.

${ }^{20}$ Bukhari Umar, Ilmu Pendidikan Islam (Jakarta: Amzah, 2010), 84.
} 
merupakan sarana penanaman norma dalam pikiran siswa, sehingga dapat hidup berdampingan dengan orang lain. Kepala sekolah dan guru harus bekerja keras untuk norma dalam pikiran siswa. Mereka harus mengambil langkah yang tepat untuk mennyukseskan proses pembelajaran dan norma dalam pikiran siswa melalui lingkungan sekolah secara baik. Seorang guru agama Islam dianggap dapat mengajak sifat baik terhadap siswa dan bisa membiasakan nilai inti sesuai ajaran Islam dalam praktik kehidupan sehari-hari. Ditemukan banyak sekali para siswa yang kurang berkarakter dan berakhlakul karimah, bukan karena kesalahan guru, tetapi sebenarnya karakter ini milik siswa, sehingga menjadi tugas pendidik untuk membantu dan mendorong mereka untuk menjadi orang baik dengan disiplin.

Pendidik menggunakan kebiasaan untuk mengajar siswa tentang hakikat mata pelajaran. Fungsi adiktif seperti menguatkan suatu benda atau zat yang telah masuk ke dalam hati penerima informasi (siswa). Proses pembiasaan berfokus pada pengalaman langsung, berguna sebagai penghubung antara perilaku peran dan fungsi kecanduan lainnya, sebagai pelindung moral yang dibangun dalam tubuh manusia, dan mengarah pada penjelasan yang mendalam dan umum, membuat orang lebih percaya diri dan tekad untuk memegang objek akhlak yang telah diyakini. Kecanduan ini sangat diperlukan untuk pembentukan kepribadian karena hati seseorang sangat mudah berubah, bahkan jika perilaku yang sedang berlangsung tampaknya telah dimasukkan ke dalamnya. Maksudnya adalah setelah siswa memahami dan menjalankan perilaku tersebut, jika guru mengajarkannya dengan cara ini, dia akan menjadi kecanduan. Dengan melakukan hal tersebut secara berulang-ulang, siswa dapat membiasakan diri melakukan perbuatan baik. Untuk menumbuhkan karakter disiplin di kalangan siswa, sebaiknya membiasakan siswa menaati peraturan sekolah agar karakter disiplin dapat diterapkan pada siswa. Tindakan disiplin harus diambil sesuai dengan peraturan sekolah. Hal ini dapat dilihat dalam kehidupan sehari-hari siswa pada saat jam sekolah. Agar tidak terlambat, harap menyelesaikan tugas tepat waktu dan memakai seragam sekolah sesuai dengan peraturan sekolah.

Selain itu, karena metode keteladanan Islam itu sendiri, maka keteladanan umat Islam adalah Nabi Muhammad SAW, Nabi memiliki akhlak yang baik dan memiliki sikap disiplin dalam merancang orang-orang yang meniru. Siswa belajar, meniru dan menerapkan perilaku idolanya. Ketika siswa menemukan teladan yang baik di lingkungannya, mereka akan memperoleh nilai-nilai baik yang dapat berkembang 
menjadi perilaku dan karakter yang baik. ${ }^{21}$ Memimpin dengan memberi contoh akan mengesankan siswa, memungkinkan mereka untuk membentuk sikap dan perilaku, memberi mereka bimbingan, dan mempersiapkan mereka untuk membangun kehidupan sebagai anggota masyarakat. Pendidik dapat memimpin dengan memberi contoh dan membuat mereka merasa positif. Untuk melihat apakah ada tanda-tanda panutan, siswa dapat memeriksa salah satunya untuk melihat apakah ada contoh mentor pribadi. ${ }^{22}$ Demikian pula siswa dapat meniru beberapa contoh, pedoman, dan perilaku dari perspektif kelembagaan, sehingga pemahaman mereka tentang nilai-nilai tersebut tidak akan bertentangan dengan kehidupan mereka.

Siswa juga harus diberikan penyuluhan tentang pembentukan karakter melalui pendidikan Islam. ${ }^{23}$ Sebenarnya, setiap orang memiliki kemampuan untuk menyerap kata-kata yang didengarnya, tetapi hanya perlu diulang beberapa kali sebelum dapat diserap ke dalam jiwa. Nasihat adalah cara yang dapat diandalkan untuk membuat siswa tetap disiplin. Melalui metode bimbingan belajar, akan memberikan dampak yang signifikan bagi siswa, membuat mereka memahami pentingnya yayasan, membekali mereka dengan karakter yang baik dan membekali mereka dengan prinsip-prinsip Islam serta menggerakan siswa ke martabat yang tinggi. ${ }^{24}$ Langkah selanjutnya adalah mengeluarkan teguran. Isi teguran dari siswa yang tidak disiplin sering terjadi saat berada di sekolah, ketika orang melakukan kesalahan dan menjadi teralihkan. Dalam pengertian ini, membuat kesalahan dengan signifikansi kemampuan masing-masing. Berbagai penyimpangan dari aturan atau undang-undang menjadi tidak terelakkan lagi. Oleh karena itu, harus menyertakan peringatan atau warning dan perbaikan untuk mencegah masalah lebih lanjut.

\section{Kesimpulan}

Materi pendidikan Islam memegang fungsi yang baik dalam membentuk karakter siswa yang disiplin. Karena pendidikan Islam mampu menjadikan peserta didik lebih berdisiplin, beradab, terdidik, dan bertakwa, serta membantu mereka menjadi manusia yang berakhlak mulia. Materi pelajaran pendidikan agama Islam menunjukkan

\footnotetext{
${ }^{21}$ Ahmad Falah, Aspek-Aspek Pendidikan Islam (Yogyakarta: Idea Press, 2010), 12.

${ }_{22}^{2}$ Mukhlas Samani dan MS Hariyanto, Pendidikan Karakter (Bandung: PT Remaja Rosdakarya, 2012), 18.

${ }^{23}$ Hasan Basri, Filsafat Pendidikan Islam (Bandung: Pustaka Setia, 2019), 28.

${ }^{24}$ Agus Zaenul Fitri, Manajemen Kurikulum Pendidikan Islam (Bandung: Alfabeta, 2013), 37.
} 
pembentukan karakter disiplin, menjadi sikap dalam pribadi siswa saat berada sekolah dan merupakan metode teladan bagi guru untuk menunjukkan dan menyampaikan perilaku disiplin kepada siswa dan memberikan saran dan masukan kepada siswa sesuai dengan aturan dan ajaran yang ada dalam Islam.

\section{Referensi}

Akip, Muhamad, dan Ahmad Taufik. "Konsep Pendidikan Akhlak Perspektif Ibnu Qoyyim Al Jauziyyah Dan Bisri Mustofa." El-Ghiroh: Jurnal Studi Keislaman 19, no. 1 (1 April 2021): 15-32. https://doi.org/10.37092/el-ghiroh.v19i1.278.

Arifin, Zaenal, dan Moh Turmudi. "Character of Education in Pesantren Perspective." Tribakti: Jurnal Pemikiran Keislaman 30, no. 2 (8 Juli 2019): 335-48. https://doi.org/10.33367/tribakti.v30i2.823.

Basri, Hasan. Filsafat Pendidikan Islam. Bandung: Pustaka Setia, 2019.

Doni Kusuma. Pendidikan Karakter: Strategi Mendidik Anak di Zaman Global. Jakarta: Grasindo, 2017.

Falah, Ahmad. Aspek-Aspek Pendidikan Islam. Yogyakarta: Idea Press, 2010.

Fitri, Agus Zaenul. Manajemen Kurikulum Pendidikan Islam. Bandung: Alfabeta, 2013.

Hidayat, Nur, Danarti, dan Sri Darwati. "Disiplin Positif; Membentuk Karakter Tanpa Hukuman," 3 Agustus 2016. http://publikasiilmiah.ums.ac.id/handle/11617/7840.

Husaini, Adian. Filsafat Ilmu Perspektif Barat dan Islam. Jakarta: Gema Insani, 2013.

Ihsan, Hamdani. Filsafat Pendidikan Islam. Bandung: Pustaka Setia, 2017.

Karim, Iqbal, dan Ahmad Masrukin. "Peran Program Wali Asuh Dalam Membentuk Kedisiplinan Santri Pondok Pesantren Al Mahrusiyah Putra Lirboyo.” Indonesian Journal of Humanities and Social Sciences 1, no. 3 (30 November 2020): 16572. https://www.ejournal.iai-tribakti.ac.id/index.php/IJHSS/article/view/1456.

Muhlisin, Muhammad, dan Edi Nurhidin. "Konstruksi Kedisiplinan Melalui Habituasi Kegiatan Keagamaan." Indonesian Journal of Islamic Education Studies (IJIES) 3, no. 2 (2020): 236-51. https://doi.org/10.33367/ijies.v3i2.1395.

Penyusun, Tim. Konsep dan Pedoman Penguatan Pendidikan Karakter; Tingkat Sekolah dasar dan Sekolah Menengah Pertama. Jakarta: Kemdikbud, 2019. https://cerdasberkarakter.kemdikbud.go.id/?wpdmpro=buku-konsep-danpedoman-ppk.

Rohman, Arif. Pendidikan Komparatif Dasar-dasar Teori Perbandingan Pendidikan Antar Bangsa. Yogyakarta: Aswaja Pressindo, 2013.

Salsabila, Unik Hanifah, Annisa Septarea Hutami, Safira Aura Fakhiratunnisa, Wulan Ramadhani, dan Yuike Silvira. "Peran Pendidikan Islam Terhadap Pembentukan Karakter Disiplin Peserta Didik.” Jurnal Intelektual: Jurnal Pendidikan Dan Studi Keislaman 10, no. 3 (2020): 329-43. https://doi.org/10.33367/ji.v10i3.1391.

Samani, Mukhlas, dan MS Hariyanto. Pendidikan Karakter. Bandung: PT Remaja Rosdakarya, 2012. 
Sobri, Muhammad, Nursaptini Nursaptini, Arif Widodo, dan Deni Sutisna. "Pembentukan Karakter Disiplin Siswa melalui Kultur Sekolah." Harmoni Sosial: Jurnal Pendidikan IPS 6, no. 1 (6 Maret 2019): 61-71. https://doi.org/10.21831/hsjpi.v6i1.26912.

Sofanudin, dkk., Aji. Literasi Keagamaan dan Karakter Peserta Didik. Disunting oleh Aji Sofanudin dan Ahmad Muntakhib. Yogyakarta: Diva Press, 2020.

Tafsir, Ahmad. Ilmu Pendidikan Perspektif Islam. Bandung: Remaja Rosdakarya, 2018.

Tantowi, Ahmad. Pendidikan Islam di Era Transformasi Global. Semarang: Pustaka Rizki Putra, 2008.

Taufik, Ahmad. "Dakwah Pasca Covid 19." Jurnal Khabar: Komunikasi Dan Penyiaran Islam 2, no. $2 \quad(30 \quad$ Desember 2020): 167-75. https://doi.org/10.37092/khabar.v2i2.249.

Uhbiyati, Nur. Dasar-dasar Ilmu Pendidikan Islam. Semarang: Pustaka Rizki Putra, 2013.

Umar, Bukhari. Ilmu Pendidikan Islam. Jakarta: Amzah, 2010.

Zubaedi. Desain Pendidikan Karakter; Konsepsi dan Aplikasinya dalam Lembaga Pendidikan. Jakarta: Kencana, 2011. 